\title{
SSynthesis
}

International Scientific Conference of IT and Business-Related Research

\section{INFORMACIONO-KOMUNIKACIONE TEHNOLOGIJE I ODRŽIVOST U FUNKCIJI STVARANJA KONKURENTNOG TURISTIČKOG PROIZVODA}

\author{
INFORMATION-COMMUNICATION TECHNOLOGY AND SUSTAINABILITY AS THE BASIS \\ FOR CREATING A COMPETITIVE TOURISM PRODUCT
}

\author{
Ivana Damnjanović, Lora Petronić Petrović, Biljana Tešić, Sonja Urošević \\ Poslovni fakultet Valjevo, Univerzitet Singidunum, Železnička 5, Valjevo, Srbija
}

\begin{abstract}
Apstrakt:
Globalizacija je uslovila promene u turizmu, koje sa jedne strane podrazumevaju neprekidan razvoj informaciono-komunikacionih tehnologija (IKT), a sa druge primenu principa održivosti u cilju pružanja jedinstvenih i kvalitetnih turističkih iskustava.

U savremenom turizmu, IKT se može posmatrati kao glavni izvor inovacije, strateške diferencijacije i konkurentske prednosti. Potrošači postaju tehnološki osvešćeniji i oslanjaju se na IKT u procesu ko-kreiranja sopstvenih iskustava. Internet omogućava pristup neograničenoj količini informacija, doprinosi stvaranju jedinstvenog turističkog proizvoda i njegovom marketingu. Imajući u vidu broj korisnika interneta u svrhe putovanja, se može reći da ima snažan potencijal kao sredstvo za privlačenje i zadržavanje potrošača u turizmu. Pojava Veb 2.0 omogućila je korisnicima da sami kreiraju sadržaj, koji je od presudnog značaja za razvoj društvenih mreža čija se uloga u turizmu jasno vidi na osnovu statističkih podataka. Uprkos određenim ograničenjima u upotrebi IKT u turizmu, jedna od najvećih prednosti jeste konkurentniji i kvalitetniji proizvod usaglašen sa potrebama tržišta.

Savremeni oblici turizma tesno su povezani sa principima održivosti čija se primena oslanja na upotrebu kompleksnih sistema za planiranje i upravljanje zasnovanih na IKT. Imajući u vidu karakteristike savremene odgovorne turističke tražnje, primena IKT može se smatrati osnovom konkurentske prednosti turističkog proizvoda.
\end{abstract}

\section{Ključne reči:}

turizam, informaciono-komunikacione tehnologije, održivost, konkurentnost.

\section{UVOD}

Svet se nalazi u procesu konstantne promene. Ono što je karakteristika faze u kojoj se sada nalazi jeste njegovo smanjenje u vremenu i prostoru pomoću različitih savremenih mehanizama. Takva kompleksna dešavanja su dobila naziv globalizacija. „Globalizacija se generalno posmatra kao proces koji uključuje kompresiju dimenzija vreme i prostor i karakteriše je veći stepen međupovezanosti društveniih grupacija na različitim nivoima" (Cornelissen, 2005, str. 27). Globalizacija je skraćenica za globalne integracije (International Union for Conservation of Nature, 2008, str. 4-5). Ona ne podrazumeva samo ekonomsku dimenziju, već i društvenu, kulturnu, jezičku, političku, tehničku i ekološku integraciju. Prema Klancniku (2006, str. 58), glavni efekti koje globalizacija ima na turističku destinaciju su: povećana tražnja i konkurencija, veći pritisak za saradnjom, inovacijom proizvoda, specijalizacijom, brendiranjem i višim kvalitetom usluga kao i sve većim nedostatkom kapitala za finansiranje neophodnih investicija sa ciljem ispunjenja budućih ciljeva.

\section{Abstract:}

Globalization has triggred change in the tourism industry, which implies the continual development of information and communication technologies (ICT) on the one hand, and the application of the sustainability principle on the other, with the aim to provide a unique and high-quality tourism experience.

In modern tourism, ICT can be perceived as a major source of innovation, strategic differentiation and competitive advantage. Consumers are becoming even more technologically-aware and rely on ICT in the process of co-creation of their own experiences. Internet provides access to unlimited amount of information, and contributes to creating a unique tourism product and its marketing. Given the number of Internet users fortravel purposes, the Internet is viewed as an important means of attracting and retaining tourists. The emergence of Web 2.0 has enabled the users to create their own content, which is of vital importance for the development of social networks whose role in tourism can be seen in the users' statistics. Although there are certain limitations in the use of ICT in tourism, a competitive and quality product adjusted to the market needs is among the most important benefits.

Modern forms of tourism are closely related to the principles of sustainability whose application relies on the use of complex planning and management systems based on ICT. Bearing in mind the characteristics of contemporary responsible tourism demand, the competitive advanatage of tourism product is based on the use of ICT.

\section{Key words:}

tourism, information-communication technologies, sustainability, competitiveness.

Turizam je postao globalan, sa razvojem savremenih vidova prevoza, ali ono što će uticati na njegov razvoj u budućnosti su promene proistekle iz procesa globalizacije - pojava i razvoj informaciono-komunikacionih tehnologija (informationcommunication technologies / ICT) i briga o životnoj sredini, lokalnoj kulturi i načinu života na destinacijama kroz razvoj održivih oblika turizma. Pod okriljem globalizacije su se našle promene vezane za turizam, IKT i održivost, ali njihovom simbiozom se može stvoriti novi globalni pravac razvoja.

Uloga informaciono-komunikacionih tehnologija će biti sve značajnija u pogledu premošćavanja razlika u vremenu i prostoru, koje postoje među različitim i po svetu raširenih aktera u procesu kreiranja i isporučivanja turističkih proizvoda i usluga. Prema Go-u i Klooster-u (2006, str. 137), sa jedne strane se nalazi sistem za upravljenje sadržajem koji omogućava turistima da postanu ko-kreatori sopstvenih turističkih iskustava. Sa druge, kroz onlajn interakciju turista se može pratiti kakve su njihove preferencije, te proizvode i usluge prema tome prilagođavati. 


\section{ULOGA INFORMACIONO-KOMUNIKACIONIH TEHNOLOGIJA U SAVREMENOM TURIZMU}

Savremeni svet prolazi kroz sve brži proces globalizacije koja ruši sve prostorne i druge granice, a posebno s razvojem IKT. S obzirom na neprekidan razvoj novih tehnologija i mogućnosti, globalizacija zaista može da predstavlja koncepciju koja podrazumeva u najmanju ruku stalnu povezanost svih ljudi bez obzira da li se radi o poslovanju ili slobodnom vremenu. Kako turizam posmatran sa gledišta pružalaca usluga ili korisnika tih usluga jeste istovremeno i poslovanje i provođenje slobodnog vremena, IKT ima veliku ulogu u novim pravcima razvoja sa značajnim izgledima da tako bude i ubuduće.

Prema Buhalisu i O’Connor-u (2005), glavni trend koji je u osnovi svih razvoja predstavlja integracija hardvera, softvera i inteligentnih aplikacija kroz umrežavanje i napredne korisničke interfejse.

IKT imaju značajan uticaj, između ostalog, i na razvoj turizma u svakom pogledu. IKT pruža mogućnost potrošačima da identifikuju, prilagode sopstvenim potrebama i kupe turističke proizvode, kao i da podrže globalizaciju ove privredne grane obezbeđujući sredstva za razvoj, upravljanje i distribuciju ponude širom sveta čime IKT igraju presudnu ulogu u konkurentnosti turističkih organizacija i destinacija (Buhalis \& O'Connor, 2005).

Kako Neuhofer, Buhalis i Ladkin zaključuju u svom istraživanju (2012, str. 44), stvaranje iskustva za turiste predstavlja osnovu za uspešan marketing i menadžment destinacije. Pored toga, oni navode da konkurentnost destinacije u velikoj meri zavisi od nemogućnosti jedne destinacije da se zameni drugom ili od toga da destinacija ne predstavlja repliku neke druge. $\mathrm{Na}$ taj način je moguće postići konkurentnost kroz stvaranje bogatih i jedinstvenih iskustava. Njihovo istraživanje se oslanja na dve promene koje značajno utiču na to kako će destinacija stvarati iskustva. Prva promena je da turisti učestvuju u stvaranju sopstvenog iskustva, a druga da se tehnologija može koristiti u te svrhe. Takođe, navode da iako se većina destinacija fokusira na stvaranje iskustva na samoj destinaciji, zajedničko stvaranje iskustva u kojem ulogu imaju i sami turisti, može dostići novi nivo uz upotrebu tehnologije. Tako stvaranje iskustva dobija više faza i pomera se sa same destinacije u virtuelni prostor dostupan turisti pre, za vreme i nakon putovanja. Prema tome, „tehnologiju treba shvatiti kao glavni izvor inovacije, strateške diferencijacije i konkurentsku prednost pri uspešnom zajedničkom stvaranju iskustva u budućnosti“ (Neuhofer et al., 2012, str. 44).
Dakle, uloge IKT u turizmu danas mogu biti brojne i raznovrsne. U društvu za koje se može reći da je informatičko i zavisno od informacija, informacija predstavlja ključni element i u turizmu, te je i uloga IKT neizostavna, ne samo u svakodnevnom funkcionisanju, već i poboljšanju usluga i pozicije na tržištu.

Ključni faktori koji utiču na upotrebu IKT u turizmu su:

- IT edukacija i obuka donosilaca odluka, menadžera i drugih aktera u okviru turizma; integracija različitih sektora poput transporta, smeštaja, itd.; tehnička infrastruktura;

- ljudska infrastruktura koja podrazumeva obučene ljude, viziju i menadžment;

- pravna infrastruktura;

- IKT kultura (stvaranje i održavanje IKT okruženja, održavanje i osvežavanje veb-sajtova,

IKT obuke za radnike svih nivoa, ostvarivanje elektronskih veza između svih povezanih sektora) (Deepthi, 2008).

Turizam koji integriše IKT u različite aspekte funkcionisanja može nazvati e-turizmom i mogu se pratiti njegovi trendovi (Buhalis \& O’Connor, 2005), kao što se može videti u tabeli 1. Buhalis $(2011$, str. 6) definiše e-turizam kao primenu IKT u turizmu i navodi da e-turizam spaja tri odvojene discipline: menadžment poslovanja, informacione sisteme i upravljanje informacijama, i turizam.

\section{IKT U FUNKCIJI ISPUNJAVANJA POTREBA SAVREMENIH POTROŠAČA U TURIZMU}

Fokusiranost na potrošače proizilazi iz činjenice da su oni sve više tehnološki osvešćeni, te im pružanje informacija vezanih za destinaciju omogućava priliku da traže posebnu vrednost za novac, ali i vreme koje moraju da ulože u organizovanje putovanja. Pružanje tačnih i pravovremenih informacija može povećati zadovoljstvo potrošača i doneti uspeh organizaciji koja se bavi turizmom na takav način. Pored toga, da bi se mogle ispuniti želje i potrebe potrošača i privući novi, neophodno je te želje i potrebe najpre identifikovati. IKT može dati svoj doprinos u procesu prikupljanja, skladištenja i obradi takvih podataka. Uz pomoć IKT, oni se mogu prikupljati u svakoj fazi pružanja usluge - pre, tokom i nakon putovanja - i na taj način bolje shvatiti izbori i ponašanja, kao i druga pitanja za koja su potrošači zainteresovani. Iz tog razloga organizacije koje se bave turizmom bi trebalo da razviju personalizovane usluge podržane tehnologijom kako bi se ispunile ustanovljene individualne potrebe potrošača (Buhalis \& O’Connor, 2005).

\begin{tabular}{|c|c|c|c|}
\hline $\begin{array}{c}\text { POTROŠAČ } \\
\text { fokus na potrošače }\end{array}$ & \multicolumn{2}{|c|}{ TRENDOVI U E-TURIZMU } & $\begin{array}{c}\text { DISTRIBUCIJA } \\
\text { omogućena partnerstva }\end{array}$ \\
\hline \multirow{2}{*}{ 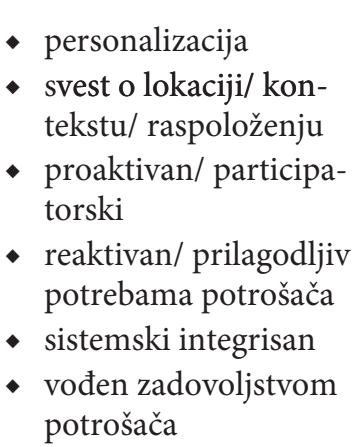 } & $\begin{array}{r}\text { KOM } \\
\text { Vođen }\end{array}$ & $\begin{array}{l}\text { VIJA } \\
\text { fitom }\end{array}$ & \multirow{2}{*}{$\begin{array}{l}\text { - } \text { virtuelne organizacije } \\
\text { - } \text { razteroperabilnost } \\
\text { nosti }\end{array}$} \\
\hline & $\begin{array}{l}\text { Prihodi } \\
\text { - širenje tržišta i operacija } \\
\text { - marketing i promocija } \\
\text { - direktna distribucija } \\
\text { - eksenadžment prihoda } \\
\text { strategija }\end{array}$ & $\begin{array}{l}\text { Troškovi } \\
\text { - interna integracija } \\
\text { - redukcija posredovanja } \\
\text { - inteligentna nabavka }\end{array}$ & \\
\hline
\end{tabular}

Tabela 1. Trendovi u e-turizmu proistekli iz upotrebe IKT

Izvor: Klancnik, R.V. (2006) 
Opšte usvajanje IKT u turizmu je ostavilo fundamentalne posledice po način na koji se putovanje planira, a turistički proizvod kreira i konzumira (Neuhofer et al., 2012, str. 38). Prema istom izvoru, potrošači su postali sve više informisani i aktivni što je dovelo do velike promene u sistemu koji turizam kao grana privrede predstavlja. Ta promena podrazumeva da su potrošači postali aktivno uključeni i u proces potrošnje i proizvodnje u turizmu. Oni sada, umesto već pripremljenih paketa, žele autentičnost i očekuju balans između mnogo iskustva i slobode da sopstvena iskustva ko-kreiraju. Upotrebom IKT, a posebno interneta i mogućnosti koje on pruža potrošači su u prilici da više nego ikad u tom procesu učestvuju. Prema Neuhofer et al. (2012), od presudnog je značaja za destinacije da olakšaju potrošačima da ko-kreiraju iskustva, jer se na taj način povećava i vrednost stečenog iskustva, što predstavlja ključ za rast i inovacije, kao i izvor konkurentske prednosti. Takođe, navode da usvajanje IKTu tom procesu predstavlja sastavni deo konkurentnosti i glavni izvor konkurentske prednosti. Prema autorima, posebno veliki potencijal u tom procesu ima internet kao sredstvo za ko-kreaciju iskustva.On omogućava turistima bolju komunikaciju i interakciju, a destinacijama da stvore blisku vezu sa turistima.

\section{ULOGE INTERNETA U PRUŽANJU TURISTIČKIH USLUGA}

Internet predstavlja sastavni deo IKT i može se definisati kao mreža koja povezuje brojne mreže i korisnike širom sveta i kao mreža koju niko posebno ne poseduje (Buhalis, 2011, p. 4).

Kako se doživljaj i iskustvo ne stiču samo na samoj destinaciji, već i pre dolaska na nju i po odlasku sa nje, uloga koja u tom procesu ima internet je posebno značajna. Pojavom interneta, društvenih mreža i virtuelnih svetova turisti su u mogućnosti da ocene destinaciju pre njihovog fizičkog putovanja na nju. Posebno im društvene mreže omogućavaju da dožive destinaciju kroz utiske drugih potrošača, i od onih koje poznaju i potpuno nepoznatih (Neuhofer et al., 2012, str. 41). Društvene mreže istovremeno igraju i veliku ulogu u fazi nakon putovanja u procesu interakcije i deljenja iskustava onlajn.

Upotreba interneta u svrhe pružanja turističkih usluga je sve veća. Prema Oliver et al. (2009, str. 93-94), internet je postao toliko popularan u turizmu, da drugo mesto među korisnicima interneta zauzimaju oni koji se interesuju za turizam i putovanje. Razlozi za takvo usvajanje interneta u oblasti turizma i od strane pružalaca i korisnika usluga mogu biti brojni. Prema prethodno navedenom izvoru, poseban je značaj relevantnih informacija koje se mogu dati ili pronaći brzo po niskoj ceni i u vreme kada turista želi da je pronađe. Pored toga, internet omogućava pružaocima usluga da brzo i na vreme reaguju na potrebe i želje potrošača. Da bi to mogli da učine, pružaoci različitih usluga ili komponenti jednog turističkog proizvoda se putem interneta lako i brzo povezuju time stvarajući jedinstven celokupan proizvod za potrošače. To podrazumeva i zajednički nastup na tržištu i koordinisan internet marketing. Oliver et al. (2009) su izdvojili šest glavnih prednosti koje proističu iz upotrebe internet marketinga u oblasti turizma i putovanja:

- mogućnost ciljanja na specifične tržišne segmente,

- mogućnost sakupljanja informacija o pojedinačnim korisnicima kao osnova za buduće planiranje i razvoj,

- sposobnost izbora pojedinaca koji pristupaju infomaciji i konstruisanje profila potrošača, kroz dalje praćenje,

- mogućnost da se informacija isporučuje globalno 24 sata dnevno, 7 dana u nedelji u trenutku kada potrošač traži informaciju, i na taj način se osigurava sinhrona isporuka informacije
- fleksibilnost i brzina kojima se onlajn kampanje mogu primenjivati,

- nivo interaktivnosti koja uključuje potrošača u promotivni proces.

Posebno je značajna uloga interneta u procesu traženja informacija od strane potencijalnih turista u fazi pre putovanja, pogodan je za to i zbog svoje interaktivne prirode i zabavnog karaktera. Internet ne predstavlja samo potrošačko okruženje, već predmet potrošnje (Beirne \& Curry, 1999). Prema rezultatima istraživanja koje su sproveli Beirne i Curry (1999), informacije o destinacijama koje su ispitanici nalazili na internetu su pozitivno uticale na promenu njihove percepcije o destinacijama, te na odluku o poseti jednoj od njih. Sa druge strane, ukoliko je nedovoljna količina informacija o destinaciji koja se može pronaći na internetu, potrošači mogu eliminisati destinaciju iz svog izbora, posebno u slučaju ukoliko je dostupna dovoljna količina i oblik informacija o drugim destinacijama za koje su zainteresovani.

Da bi se pokazalo koliki potencijal internet kao sredstvo za privlačenje i zadržavanje potrošača u turizmu ima, neophodno je osvrnuti se na broj korisnika interneta globalno posmatrano. Preko 2.7 milijardi ljudi je koristilo internet u 2013. godini, što čini 39\% globalne populacije (International Telecommunication Union \& ICT Data and Statistics Division, 2013, str. 2), pri čemu je Evropa region sa najvećom stopom penetracije tržišta (75\%). Prema istom izvoru, u 2013. godini 41\% svih domaćinstava na svetu (750 miliona domaćinstava) je bilo povezano sa internetom. U razvijenim zemljama, 78\% svih domaćinstava je povezano sa internetom, dok je taj procenat u zemljama u razvoju samo $10 \%$. Najviše ih je u Evropi (77\%), a najmanje $\mathrm{u}$ Africi (7\%). U istoj godini, na svetu je postojalo skoro isto onoliko mobilnih pretplatnika koliko i ljudi na planeti -6.8 milijardi. Globalna penetracija mobilnih telefona je 96\% (128\% u razvijenim i $89 \%$ u zemljama u razvoju) i tržište je zasićeno, te stope rasta padaju na najniže nivoe ikada (International Telecommunication Union \& ICT Data and Statistics Division, 2013, str. 1).

Imajući u vidu činjenicu da internet predstavlja sastavni deo života današnjice, posebno u razvijenim zemljama i sa značajnim porastom u zemljama u razvoju, za očekivati je da implikacije koje ima po turizam budu nezaobilazne. Od trenutka kada je internet postao suštinsko sredstvo komunikacije i u turizmu, došlo je i do promene u strukturi celokupne grane privrede. Razvoj i sve više sofisticiran internet predstavlja najveći trend koji je uticao na odgovorni turizam na mnogo pozitivnih načina (SNV Netherlands Development Organisation, 2009, str. 24). Deepthi (2008) navodi nekoliko promena koje su nastale:

- povećana je direktna prodaja kupcima;

- veći broj novih posrednika poput internet portala koji su specijalizovani za prodaju turističkih proizvoda;

- kupci sada imaju pristup kanalima distribucije koje su tradicionalno koristili turoperatori putem interneta;

- kompanije mogu redovno da vrše izmene na svojim proizvodima i uslugama a koje se zasnivaju na potrebama i očekivanjima klijenata kroz redovnu interakciju putem interneta;

- povećana transparentnost i efikasnost odnosa između kupca i menadžmenta;

- promena u ponašanju potrošača - oni sada traže bolje usluge, jasniji su u pogledu sadržaja i detalja putovanja, svesniji su cene i često prave poređenja između dva proizvoda.

Prema statistici o onlajn putovanju za 2012. godinu (Online travel statistics 2012), čak $87 \%$ putnika je koristilo internet za 
planiranje svog putovanja. Među najpopularnije onlajn aktivnosti za putnike spadaju:

- $62 \%$ njih je koristilo internet za istraživanje budućeg putovanja,

- $45 \%$ je dobilo početnu ideju za putovanje,

- $43 \%$ čita komentare drugih putnika,

- $31 \%$ gleda video sa putovanja,

- $24 \%$ čita blogove koji se bave putovanjima,

- $16 \%$ postavlja svoje komentare vezane za putovanje,

- $11 \%$ postavlja video sa prethodnog putovanja.

Pored toga, među najpopularnije aktivnosti nakon putovanja spadaju (Online travel statistics 2012):

- 76\% ljudi postavlja svoje fotografije sa putovanja na društvenu mrežu,

- 55\% njih „lajkuje“ Facebook strane koje su posvećene putovanju,

- $46 \%$ njih postavlja komentare o hotelu,

- $40 \%$ njih postavlja komentare o atrakcijama,

- $40 \%$ njih postavlja komentare o restoranima.

\section{ZNAČAJ VEB 2.0 U SAVREMENOM TURIZMU}

Bitno je navesti način na koji su sve navedene promene omogućene. Naime, došlo je do razvoja druge generacije vebaplikacija, poznatih pod imenom Veb 2.0 koje omogućavaju potrošačima da međusobno komuniciraju na lakši način. Prema Buhalisu (2011, str. 4), veb (World Wide Web, WWW ili jednostavno Web sa značenjem „mreža“) predstavlja multimedijalni protokol koji koristi internet kako bi omogućio skoro trenutnu distribuciju dokumenata i revolucionarizovao interaktivnost između kompjutera i servera. Prema Middleton-u et al. (2009, p. 243-249), pojava Veb 2.0 je dovela do komercijalnih veb-sajtova koji se zasnivaju na „sadržaju kreiranom od strane korisnika“, odnosno materijalima koje postavljaju potrošači, a ne organizacija kojoj sajt pripada. Veb 2.0 je proizvod razvoja veba od svoje prvobitne uloge mesta na kojem su komercijalne organizacije (kao što su turoperatori ili hoteli) i predstavnici javnog sektora (poput turističkih ili destinacijskih organizacija) pružali informacije potencijalnim potrošačima putem veb-sajtova. Isti autori navode da danas potencijalni putnici proveravaju informacije sa zvaničnih sajtova poredeći ih sa stavovima i iskustvima drugih posetilaca na nezvaničnim sajtovima. Na ovaj način, Veb 2.0 predstavlja promenu pristupa modernom marketingu sa "fokusiranog na kompaniju" na "fokusiran na potrošača”.

Kao proizvod primene Veb 2.0 u turizmu, 2003. godine je po prvi put skovan termin „Putovanje 2.0“ (Travel 2.0) i odnosi se na to koliko je važno razvijati onlajn zajednice i forume sa centralnom temom putovanja (SNV Netherlands Development Organisation, 2009, str. 25). Može se zaključiti da se turisti okreću ka direktnim oblicima međusobne interakcije u potrazi za autentičnijim turističkim iskustvima i povezanosti.

Pored pojave Veb 2.0, jednu od najznačajnijih pojava u IKT predstavlja razvoj softverskih sistema koji podržavaju i unapređuju upotrebu kompjuterskih mreža. Da bi se brojnim veb-sajtovima na internetu uopšte moglo pristupiti bio je neophodan razvoj pretraživača (search engines) kojima se biraju oni sajtovi koji zadovoljavaju interese korisnika. Prema Middleton-u i saradnicima (2009, str. 249), Gugl (Google) je postao dominantan „portal“ putem kojeg ljudi pretražuju informacije o putovanju i odmorima kao i u svakom drugom aspektu života.

Tehnologija pretraživača je takođe od vitalnog značaja za razvoj društvenih mreža poput onih kao što su Facebook, Twitter ili My Space. Pomoću njih, korisnici dobijaju unapred pripre- mljene sajtove koje pune detaljima po svom izboru, a između ostalog i o putovanjima i sličnim interesovanjima. Takođe, na isti način se povezuju sa prijateljima i ljudima sa kojima dele interesovanja. Na svim ovakvim sajtovima je omogućeno veoma precizno segmentiranje tržišta, posebno grupa sa specijalnim interesovanjima, te su društvene mreže bitan sastavni deo marketinga u oblasti turizma (Middleton et al., 2009, str. 249). Uloga društvenih mreža u turizmu se može videti iz sledeće statistike (Online travel statistics 2012):

- $70 \%$ ljudi postavlja svoj Facebook status dok su na putovanju

- $52 \%$ putnika menja svoje prvobitne planove za putovanje pod uticajem društvenih mreža

- 50\% turističkih kompanija koje su ispitane se slaže da su direktne rezervacije potekle sa društvenih mreža

- pod uticajem društvenih mreža 33\% njih promeni svoj hotel, $10 \%$ destinaciju, $10 \%$ agenta/ operatora/veb-sajt, $5 \%$ avio-kompaniju

- $7 \%$ njih otputuje u drugu zemlju pod uticajem društvenih mreža.

Dakle, u potrazi za informacijama, potencijalni potrošači mogu ići na zvanične veb-sajtove proizvoda ili kompanija koje ih interesuju. Međutim, institucionalni i zvanični veb-sajtovi čine samo $20 \%$ veb-sajtova na internetu, dok preostalih $80 \%$ čine nezvanični - blogovi, društvene mreže i mali veb-sajtovi (Hopken et al., 2009, str. 382-383) koje je razvoj Veb 2.0 omogućio. Dalje, da bi mnoštvo informacija čija količina svakodnevno raste mogla da se organizuje prema potrebama korisnika neophodna je upotreba pretraživača.

Konačno, upotreba IKT i u okviru interneta i veba, posebno u turizmu, nije bez nekih ograničenja. Informacije kojima se pristupa često mogu biti fragmentovane te se do njih može stići samo inteligentnom navigacijom što može oduzeti dosta vremena (Deepthi, 2008, str. 55). Buhalis (2011, str. 12-13) čak daje klasifikaciju tih barijera na tehnološke među kojima se nalazi nepostojanje globalnih standarda za kvalitet, sigurnost i pouzdanost, razvoj softverskih alata, nedovoljan ili preskup pristup internetu, i na netehnološke koje proističu iz navedenih. Među njima su nedostatak poverenja u elektronsko poslovanje, nerešena pravna pitanja, itd.

S tim u vezi, može se reći da se većina pružalaca usluga u turizmu nalazi tek u ranim fazama primene Veb 2.0 tehnologije, dok sa druge strane Veb 2.0 prelazi u Veb 3.0 koji se odlikuje pružanjem preciznijih informacija, te bi pružaoci turističkih usluga mogli da potrošaču obezbede korisnije i bolje povezane podatke (Tsiotsou \& Goldsmith, 2012, str. 294).

Ipak, koristi od upotrebe IKT, interneta i veba u turizmu su brojne i sveobuhvatne. Ne mogu se sa preciznošću odrediti budući uticaji IKT na e-turizam, ali se može reći da će svakako on biti fokusiran na potrošača uz pomoć novih tehnologija koje će omogućiti organizacijama da se fokusiraju na profitabilnost kroz mreže partnerstava (Buhalis \& O’Connor, 2005). Korist od integracije interneta u proizvodnju i isporuku turističkih proizvoda i usluga se vidi kroz njihovu povećanu moć pregovaranja koja proističe iz mogućnosti da trenutno pristupe tačnim i važnim informacijama i da komuniciraju direktno sa dobavljačima, na taj način snižavajući cene, navodi Buhalis (2011, str. 29-30). Isti autor zaključuje da je internet doveo do povećanog rivalstva među pružaocima turističkih usluga jer je uveo transparentnost, brzinu, pogodnost i širok spektar izbora i fleksibilnost na tržštu. 


\section{ODRŽIVOST KAO TREND U SAVREMENOM TURIZMU}

Sve je više vidljivo poslednjih decenija da poslovne strategije masovnog turizma, a posebno stvaranje profita kroz ekonomiju obima i standardizaciju rigidnih turističkih paketa, popuštaju pred novom paradigmom koju oblikuju segmentacija novih zahteva na strani tražnje, nove tehnologije, novi oblici proizvodnje i menadžmenta i novi okviri i uslovi (Wahab \& Cooper, 2001, str. 48).

Posebno se razvoj savremenih oblika turizma povezuje sa koncepcijom održivosti generalno kroz procese koji se odvijaju u ekonomiji, kulturi i politici prvenstveno u razvijenim zemljama. Odluke donete u razvijenim zemljama u smanjenom globalizovanom svetu se brzo i jednostavno prelivaju u manje razvijene ili nerazvijene zemlje. Da bi se globalizacija mogla analizirati, neophodno je obratiti pažnju na njen sastavni deo pojam održivosti i održivog razvoja (Mowforth \& Munt, 2003, str. 10). Razvoj održivih oblika turizma se posebno vezuje za nerazvijene zemlje, i prati ih stalna debata o tome u kojoj meri su razvijeni turistički proizvodi zaista održivi.

Koncepcija održivog razvoja proistekla iz globalne potrebe da se resursi zaštite našla je svoju primenu kroz turizam. Posebno je njena primena bitna kao odgovor na negativne posledice turizma na životnu sredinu, kulturu i društvo uopšte na destinacijama na kojima se dati turistički proizvodi razvijaju. Kako turizam nastavlja da se razvija širom sveta sve više različitih resursa (društvenih, kulturnih i ekoloških) ulaze u domen turizma, i na razvijenim i na nerazvijenim destinacijama, i stav prema uticajima turizma se tokom vremena menja (Telfer \& Hashimoto, 2006, str. 146). Tako se fokus sa negativnih uticaja turizma prebacio na analizu toga na koji način se resursima koji se koriste u turističke svrhe može upravljati tako da budu dostupni i budućim generacijama.

Kada se priča o promenama koje je globalizacija ostavila po pitanju turizma, može se reći i to da je došlo do pomeranja, kao i u svim drugim oblastima privređivanja, sa proizvoda masovnog turizma na alternativne oblike turizma, posebno u nerazvijenim zemljama (Mowforth \& Munt, 2003, str. 21-22).

Da bi se shvatili principi održivog turizma, neophodno je analizirati karakteristike i specifičnosti turističke tražnje koja je podstakla stvaranje održivih ili odgovornih oblika turizma. Prema jednoj studiji profila odgovornog turiste (SNV Netherlands Development Organisation, 2009), on ima društvenu svest koja je iznad proseka i stoga traži interaktivan odmor koji pruža bogatstvo iskustva koje se izrazito razlikuje od svakodnevnog života. Odgovorni turista planira sopstveno putovanje i o njemu istražuje i koristi sve tipove rezervacija. Tehnološki je vrlo osvešćen i sposoban te se u cilju organizovanja putovanja u velikoj meri oslanja na internet (SNV Netherlands Development Organisation, 2009, str. 39). Interesuju ga destinacije koje nisu na standardnim turističkim rutama, kao i kulture i sredine (lokalne tradicije, politika, religija, životna sredina) sa kojima želi da se poveže, razvijajući lične odnose dok je na odmoru. Odgovorni turista teži da koristi usluge koje doprinose lokalnim zajednicama, uključujući smeštaj, transport, zanatlijske proizvode, itd. On je spreman da plati više za usluge koje pružaju kompanije koje imaju sertifikovan kodeks ponašanja. Poseban segment odgovornih turista čine oni koji žele da putuju sa svrhom, odnosno da direktno doprinesu području u koje putuju. Stoga je rastući pokret turističke filantropije. Prema istoj studiji, odgovorni turista je visoko obrazovan, pripada svim starosnim grupama, podjednako obuhvata oba pola i ima viši raspoloživi dohodak od proseka. Najčešće dolazi iz Evrope ili Severne Amerike i to iz urbanih područja.
Konačno, globalizacija je donela promene i u sferi menadžmenta destinacija. One se danas mogu posmatrati kao kompleksni sistemi za planiranje u kojem učestvuje veliki broj aktera. Svaki od njih ima različit stepen uloge u procesu donošenja odluka, dok neki od njih nisu fizički ni prisutni na destinaciji. Zato destinacije moraju da obrate pažnju na lokalne uticaje koji proizilaze iz aktivnosti i pritisaka stvorenih negde drugde u lokalno-globalnom turističkom sistemu (Jamal \& Jamrozy, 2006, str. 166).

\section{IKT U FUNKCIJI PODRŠKE ODRŽIVOM TURIZMU}

Kako je globalizacija sa sobom donela promene poput uvođenja informaciono-komunikacionih tehnologija (IKT) u svakodnevni život i poslovanje uključujući i turizam sa jedne strane, i do razvoja održivih oblika turizma sa druge, treba pogledati i odnos koji postoji između IKT i održivog turizma.

Prema istraživanju koje su sproveli Ali i Frew (2010), razvoj održivog turizma može postati uspešna koncepcija u destinacijskom menadžmentu primenom informaciono-komunikacionih tehnologija. Isti autori navode da postoji slaba upotreba informacija u procesu donošenja odluka, dok je potencijal IKT u pružanju podrške menadžerskom donošenju odluka u turizmu neistraženo i neiskorišćeno. U osnovi razvoja održivog turizma leži proces donošenja odluka koji se fokusira na najbolju raspodelu resursa u ograničenom vremenskom periodu kojima se zadovoljavaju potrebe svih uključenih aktera. Ukoliko su menadžeru destinacije dostupne sve neophodne informacije, on može bolje da podrži planiranje kako bi osigurao održivost turizma na destinaciji. U svom radu, Ali i Frew (2010) bitne aspekte održivog razvoja turizma u kojima uloga IKT može da bude značajna: menadžment informacija, zadovoljstvo potrošača, interpretacija destinacije, efektivna partnerstva, uključenost lokalne zajednice, korišćenje energije (globalno zagrevanje i klimatske promene).

U svom istraživanju, Ali i Frew (2010) su intervjuisali i anketirali stručnjake iz oblasti e-turizma i organizacije za destinacijski menadžment (DMO) širom sveta. Svi ispitanici su se složili oko toga da IKT može biti korišćen za razvoj održivog turizma, ali je samo $4 \%$ stručnjaka iz te oblasti reklo da se IKT u velikoj meri trenutno i koristi u te svrhe. Istraživanjem se saznalo i da se IKT više koristi u te svrhe kada je već destinacija razvijena, ali ne i u početku, uglavnom zbog nedostatka finansijskih sredstava. Sa jedne strane, rezultat istraživanja predstavlja menadžment informacija kao oblast u kojoj bi IKT imao najviše koristi po razvoj održivog turizma. Sa druge strane, svi ispitanici su naveli barijere koje postoje za primenu IKT u razvoju održivog turizma. Među njima su troškovi neophodni za opremu; nedostatak znanja i shvatanja IKT aplikacija i alata i na koji način oni mogu da doprinesu, ali i vrlo ograničeno razumevanje menadžera šta održivi turizam podrazumeva kao i otpornost zaposlenih ka uvođenju IKT u te svrhe, itd.

$\mathrm{U}$ istraživanju se zaključuje da bi primena IKT aplikacija i alata poboljšala sposobnost menadžera destinacije da pretražuje i meri disperziju informacija vezanih za razvoj održivog turizma. Ove aplikacije doprinose i razvoju platformi na kojima lokalne zajednice mogu da dele svoja interesovanja i stavove vezane za razvoj održivog turizma. Istovremeno služe i izgrađnji mreža partnerstava među akterima na destinaciji. Konačno, one bi doprinele i boljoj komunikaciji sa turistima. Neuvođenje takvih inovacija bi moglo dovesti do ekonomskog i ekološkog propadanja destinacija (Ali \& Frew, 2010).

$\mathrm{Na}$ kraju, iako se IKT i internet mogu primeniti da u velikoj meri pozitivno doprinesu poštovanju principa održivosti i razvoju održivih destinacija, IKT danas može biti i jedan 
od konkurenata samom turističkom proizvodu. Naime, prema kvantitativnom istraživanju koje su sproveli Pergams i Zaradic (2006, str. 387-393), broj poseta nacionalnim parkovima u SAD je direktno povezan sa nekoliko indikatora vezanih za elektronske vidove zabave: sati gledanja televizije, video igre, gledanje filmova, poseta pozorištu i korišćenje interneta. U radu se zaključuje da rezultati istraživanja mogu biti pokazatelj promene kod ljudi od uživanja u prirodi ka tendenciji da se fokusiraju na fizički pasivne aktivnosti koje podrazumevaju upotrebu elekstronskih medija.

Dakle, inkorporiranjem IKT u razvoj održivog turizma se, pored navedenih brojnih koristi, može uticati na segment potencijalnih potrošača kojima je upotreba IKT u svakodnevnom životu pa i putovanju ključni faktor iskustva i doživljaja.

\section{REZIME}

Globalizacija je neminovno uslovila promene u turizmu koje sa jedne strane podrazumevaju neprekidan razvoj IKT, a sa druge primenu principa održivosti u cilju pružanja jedinstvenih i što kvalitetnijih turističkih iskustava u čijem stvaranju učestvuju sami turisti. Takvi trendovi u savremenom turizmu proističu iz sve veće turističke tražnje, ali i konkurencije, čija je posledica neophodna inovativnost.

U savremenom turizmu, IKT se može posmatrati kao glavni izvor inovacije, strateške diferencijacije i konkurentske prednosti turističkih organizacija i destinacija. Ona, sa jedne strane, omogućava potrošačima da identifikuju, prilagode sopstvenim potrebama i kupe turističke proizvode. Sa druge strane, na taj način se stvaraju uslovi za razvoj, upravljanje i distribuciju ponude širom sveta.

Uloge koje IKT može imati u savremenom turizmu mogu biti brojne i raznovrsne. Tako, one mogu biti integrisane u različite aspekte funkcionisanja turizma koji se naziva i e-turizmom.

Kada su u pitanju potrošači u turizmu, oni postaju sve više tehnološki osvešćeni. Oslanjaju se na IKT u procesu prikupljanja tačnih i pravovremenih informacija, kao i u aktivnom kokreiranju sopstvenih iskustava. Stoga je zadovoljstvo potrošača na taj način povećano, a konkurentnost takvog turističkog proizvoda je veća.

$\mathrm{U}$ navedene svrhe, internet kao jedan aspekt IKT je od velikog značaja. Ne samo da omogućava pristup neograničenoj količini informacija, već doprinosi stvaranju jedinstvenog celokupnog turističkog proizvoda, kao i njegovom marketingu. Imajući u vidu broj korisnika interneta globalno posmatrano, a posebno u korišćenju u svrhe putovanja pre, tokom i nakon njega, za internet se može reći da ima snažan potencijal kao sredstvo za privlačenje i zadržavanje potrošača u turizmu, sa akcentom na odgovorni turizam.

Navedene promene $\mathrm{u}$ savremenim turističkim trendovima su omogućene razvojem posebnog aspekta IKT u vidu pojave Veb 2.0 koje omogućavaju korisnicima da sami kreiraju sadržaj. Istovremeno je razvoj pretraživača imao svoju ulogu u stvaranju Veb 2.0, što je od vitalnog značaja za razvoj društvenih mreža. Njihova uloga u turizmu se jasno vidi u proučenoj statistici o upotrebi pre, za vreme i nakon putovanja. Iako se ne može reći da su potencijali Veb 2.0 iskorišćeni, u perspektivi se može razmišljati o koristima i promenama koje će Veb 3.0 uneti u turističku privredu.

Bez obzira na ograničenja upotrebe IKT, interneta i veba u turizmu, koristi su brojne i sveobuhvatne. Među najbitnije u kojima se ogleda savremeni turizam spada povećan rivalritet među pružaocima turističkih usluga, te konkurentniji i kvalitetniji proizvodi usaglašeni sa potrebama tražnje.
Savremeni oblici turizma su blisko povezani sa principima održivosti koji podrazumevaju iznalaženje načina kojima se resursima u upotrebi u turističke svrhe može upravljati tako da budu dostupni i budućim generacijama, a kroz upotrebu kompleksnih sistema za planiranje i upravljanje zasnovanih na IKT. Pored toga, savremeni turista je postao odgovorni turista kojeg, pored ostalog, karakteriše tehnološka osvešćenost i obučenost da koristi IKT i internet u procesu organizovanja putovanja, naročito na destinacije koje nisu na standardnim turističkim rutama. Stoga je, u savremenom turizmu došlo do promene fokusa sa masovnog na alternativne oblike turizma.

Imajući u vidu promene koje je globalizacija donela turizmu, potrebno je obratiti pažnju na odnos koji postoji između IKT i održivog turizma. Da bi se donele odluke u upravljanju u turizmu kojima se obezbeđuje održivost, neophodno je imati sve neophodne informacije u tom kompleksnom procesu koji mora da obuhvati veliki broj aktera. Prema tome uloga IKT i interneta u tom procesu može biti velika, a imajući u vidu karakteristike savremene odgovorne turističke tražnje, u primeni IKT može ležati osnova konkurentske prednosti turističkog proizvoda.

\section{LITERATURA}

Ali, A., \& Frew, A. (2010). ICT and its role in sustainable tourism development. Journal of Hospitality Application and Research, 5(2), 28-58.

Beirne, E., \& Curry, P. (1999). The impact of the internet on the information search process and tourism decision making. In D. Buhalis \& W. Schertler (Ed.), Information and communication technologies in tourism 1999 (pp. 88-96). Wien: Springer-Verlag.

Bishop, J. (2008). Greening globalisation. World conservation, 38(2), 4-6. Retrieved from https://cmsdata.iucn.org/downloads/00_world_conservation_2008_02.pdf

Buhalis, D., \& O'Connor, P. (2005). Information communication technology revolutionizing tourism. Tourism Recreation Research, 30(3), 7-16.

Buhalis, D. (2011). E-Tourism. Contemporary Tourism Reviews. (n.d.). Contemporary Tourism Reviews. Oxford: Goodfellow Publishers Limited.

Cornelissen, S. (2005). The global tourism system: Governance, development and lessons from South Africa. Aldershot, England: Ashgate Publishing Limited.

Deepthi, S. (2008). ICT and tourism: Challenges and opportunities. Conference on tourism in India: challenges ahead, India. Retrieved from http://dkc.engo.in/files/2012/02/ICTand-Tourism-Challenges-and-Opportunities.pdf

Go, F., \& Klooster, E. (2006). Managing globalization. In D. Dimitrios, \& C. Costa (Ed.), Tourism Management Dynamics: Trends, management and tools (pp. 137-144). Oxford, UK: Elsevier Butterworth-Heinemann.

Hopken, W., Gretzel, U., \& Law, R. (2009). Information and communication technologies in tourism. Wien, Austria: Springer-Verlag.

IGM. (2012). Online travel statistics 2012. Retrieved from http:// infographicsmania.com/online-travel-statistics-2012/

International Telecommunication Union, \& ICT Data and Statistics Division (2013). The World in 2013: ICT Facts and Figures. Retrieved from http://www.itu.int/en/ITU-D/Statistics/Pages/facts/default.aspx

Jamal, T., \& Jamrozy, U. (2006). Collaborative networks and partnerships for integrated destination management. In D. Dimitrios, \& C. Costa (Ed.), Tourism management dynamics: Trends, management and tools (pp. 164-172). Oxford, UK: Elsevier Butterworth-Heinemann. 
Klancnik, R.V. (2006). Media and communications. In D. Dimitrios, \& C. Costa (Ed.), Tourism management dynamics: Trends, management and tools (pp. 58-67). Oxford, UK: Elsevier Butterworth-Heinemann.

Middleton, V.T.C., Fyall, A., Morgan, M., \& Ranchhod, A. (2009). Marketing in travel and tourism. Oxford, UK: ButterworthHeinemann, Elsevier Ltd.

Mowforth, M., \& Munt, I. (2003). Globalisation, sustainability, development. In Tourism and sustainability: Development and new tourism in the third world. New York, USA: Routledge.

Neuhofer, B., Buhalis, D., \& Ladkin, A. (2012). Conceptualising technology enhanced destination experiences. Journal of Destination Marketing \& Management, 1, 36-46.

Oliver, D., Livermore, C.R., \& Sudweeks, F. (2009). Self-service in the internet age: Expectations and experiences. London: Springer.

Pergams, O.R., \& Zaradic, P.A. (2006). Is love of nature in the US becoming love of electronic media? 16-year downtrend in national park visits explained by watching movies, playing video games, internet use, and oil prices. Journal of Environmental Management, 80, 387-393.
SNV Netherlands Development Organisation. (2009). The market for responsible tourism products with a special focus on Latin America and Nepal. Hanoi, Vietnam: SNV Netherlands Development Organisation.

Telfer, D.J., \& Hashimoto, A. (2006). Resource management: Social, cultural, physical environment and the optimization of impacts. In D. Dimitrios, \& C. Costa (Ed.), Tourism management dynamics: Trends, management and tools (pp. 145154). Oxford, UK: Elsevier Butterworth-Heinemann.

Tsiotsou, R.H., \& Goldsmith, R.E. (2012). Strategic marketing in tourism services. Bingley: Emerald.

Wahab, S., \& Cooper, C. (2001). Globalization, national tourism policy and international organizations. In Tourism in the age of globalisation (pp. 45-65). London, UK: Routledge. 